\title{
As Técnicas de Atendimento de uma Empresa Localizada no Crato - CE
}

Ítalo Machado Lunal ${ }^{l}$ José Leandro de Almeida Neto ${ }^{2}$

\begin{abstract}
Resumo: Este trabalho apresenta conceitos de atendimento e qualidade, evidenciando também as principais técnicas que ajudam as organizações na hora das vendas, sendo ideal o funcionário aplicá-las para promover a satisfação constante da clientela. $\mathrm{O}$ atendimento se caracteriza em venda de um produto ou serviço entre duas pessoas, sendo importante salientar que a aplicação das técnicas é fundamental. O bom gestor tem a capacidade de identificar as dificuldades no atendimento e procurar soluções para melhorar aplicando técnicas eficientes. Logo, o objetivo deste trabalho é conhecer e analisar as técnicas de atendimento de uma empresa localizada no município do Crato-Ce. Para a realização desse trabalho foi feito um levantamento exploratório a partir dos conceitos de atendimento e qualidade, bem como foi desenvolvido um estudo de caso na empresa, cujos resultados foram analisados, evidenciando a existência de técnicas que contribuem para melhoria da satisfação dos clientes.
\end{abstract}

Palavras-chave: Atendimento. Qualidade. Técnicas.

\section{Custumer Service Techniques of an Enterprise Located in Crato - CE}

\begin{abstract}
This paper presents concepts of service and quality and demonstrates the key techniques that help organizations at the time of sales, being the ideal employee apply them to promote constant customer satisfaction. The service is characterized in selling a product or service between two people, it is important to note that the application of the techniques is essential. The good manager has the ability to identify the difficulties in service and seek solutions to improve applying efficient techniques. Therefore, the aim of this work is to understand and analyze the technical service of a business located in the municipality of Crato-Ce. To conduct this work was done from an exploratory survey of the concepts of service and quality as well as a case study was developed at the company, whose results were analyzed, showing the existence of techniques that contribute to improved customer satisfaction.
\end{abstract}

Keywords: Service. Quality. Technical.

\section{Introdução}

O atendimento de excelência é um fator que é exigido hoje com freqüência pela sociedade, sendo que, muitas técnicas e métodos foram elaborados com base nos dias atuais para atender as exigências dos consumidores.

Sendo assim, precisa-se fazer um bom atendimento devido à quantidade de concorrentes diretos e indiretos que existem. Para isto, as empresas hoje precisam fazer treinamentos eficazes com o departamento de vendas para transmitir as técnicas que estão sendo usadas atualmente para fidelização dos clientes, sendo elas: chamar o cliente pelo nome, dizer bom dia e obrigado escutá-los, entre outras.

\footnotetext{
Concludente do curso de pós-graduação em Administração, Finanças e Marketing da Faculdade Leão Sampaio italoluna2009@hotmail.com;

${ }^{2}$ Professor Especialista, Mestrando em Ciências da Educação, da Faculdade Leão Sampaio, leandro@ leaosampaio.edu.br
} 
Logo, este trabalho tem como objetivo geral conhecer e analisar as técnicas de atendimento de uma empresa situada no Crato - CE, tendo como objetivos específicos à demonstração das técnicas de atendimento utilizadas atualmente e a qualidade das mesmas, bem como, se os clientes estão retornando ao estabelecimento para efetuar novas compras.

Alem disso, o presente trabalho trás uma pesquisa de campo em uma empresa situada na cidade do Crato, a qual se caracteriza como pesquisa exploratória e quantitativa realizada através da aplicação de dois questionários, sendo um para os clientes e o outro para os funcionários da organização estudada.

Os dados coletados revelaram que a empresa se preocupa nas aplicações das técnicas de atendimento, transmitindo para seus colaboradores a importância das técnicas para a fidelização dos consumidores.

\section{Contexto Atual das Empresas e a Era da Informação}

Atualmente a sociedade vive um momento importante na história onde nunca foi tão fácil a troca de informações. Sendo assim, as empresas para sobreviver, precisam planejar idéias inovadoras para se manterem no mercado, tornando-se globalizadas e competitivas.

Nesse contexto, Almeida e Nogueira (2012) afirma que as transformações estão sendo muito intensas, contribuindo para irregularidades que se encontram nas empresas, sendo elas sociais ou econômicas. Ele destaca que os principais pontos atingidos foram às exigências dos clientes, avanços tecnológicos, treinamento, empregabilidade e reorganização industrial.

Todos esses fatores tiveram modificações no século XXI, onde a população se tornou mais ativa e com vontade de aprender, buscando melhoramentos para satisfazê-los. Muitas organizações mudaram seus conceitos e tiveram que se adequar ao mercado, principalmente em relação às técnicas de atendimentos utilizadas.

Contudo, destaca-se o pensamento de Nardi (2010) onde afirma que muitos dos consumidores embora de baixa renda, cerca de $87 \%$, também contribuem com essas mudanças. Recentemente, muitas organizações tiveram que ampliar o seu foco abrangendo o atendimento para a população de baixa renda, pois é ela, em grande parte, que movimentam o mercado.

Com essa reestruturação na economia, Werthein (2012) afirma que a Era da informação contribui satisfatoriamente na transformação social e econômica, relatando que a sociedade que está emergente é capitalista, buscando continuamente informações, onde se aplica o desenvolvimento 
digital. Contudo observa-se que existem lacunas nessas novas adaptabilidades, pois uns tem ferramentas de informações e outros não, ocorrendo uma exclusão digital.

Nota-se que uma das ferramentas de informações é citada por Zambon (2012), o qual afirma que as pessoas estão atualmente numa constante correria, e acessar pelo computador a internet é o meio mais rápido que elas encontram, sendo possível está conectado com o que acontece no mundo, além de utilizarem sites para realizar compras online, otimizando o seu tempo.

O mesmo autor afirma que a mudança do mercado atinge todos os gestores, pois, com a origem de novos conceitos administrativos junto com o avanço da tecnologia, as empresas precisaram encontrar novos canais para transmissão de informações e com a globalização muitos optaram por usar a internet já que atinge todos ao mesmo tempo, divulgando e vendendo virtualmente o seu produto ou serviço. Na globalização os consumidores de qualquer tipo podem fazer suas compras pela internet, com isso solicitando informações e comparando preços, eles entram em contato com as empresas que querem, podendo opinar e reclamar sobre os produtos.

\section{Exigências dos clientes}

No mercado atual os clientes estão ficando cada vez mais exigentes, cobrando informações precisas sobre os produtos e serviços que adquirem.

Marques (2012) diz que na implementação de um produto no mercado muito se escuta as exigências do consumidor, pedindo mais respeito por parte do funcionário, pois, muitos só se preocupam em vender, sem se preocupar em resolver o que o cliente necessita naquele momento. Sendo assim, os consumidores desapontados vão atrás de outras empresas que satisfaçam por completo o que desejam.

Segundo a visão de Zambon e Silva (2012), todos os consumidores têm suas próprias necessidades e observar o que eles querem é fundamental para a organização, procurando atendê-los exatamente no que exigem. Este pensamento é aceito também por Nardir (2010, p,39) quando afirma que "um atendimento de sucesso é aquele que consegue captar todas as necessidades de compra do consumidor relacionadas com o produto ou não [...]".

Observa-se que para este autor os clientes estão ficando cada vez mais exigentes seja no preço, na qualidade, entre outros fatores. As organizações com o avanço da tecnologia se adequaram ao novo mercado e tiveram que tomar decisão satisfatória em relação a como diferenciar o seu atendimento, pois, com o aumento da concorrência as ofertas dos produtos ficaram semelhantes.

Muitas vezes essas mudanças, sejam elas econômicas ou sociais estimulam a sociedade para buscar com garra seus ideais e exigindo o que querem e como querem. Se o atendimento não satisfazê- 
los, os clientes mudam com facilidade de estabelecimento, confirmando que se vive num mundo onde a competitividade aumenta entre as empresas e com isso precisa-se usar a criatividade na hora da venda para atender as exigências que são solicitadas.

Contudo, Gimeno (2010) afirma que:

\begin{abstract}
Mudança de hábitos decorrentes de forças econômicas - aumento da renda, de forças sociais, melhora na educação nos últimos anos no Brasil, aliada a um refinamento cultural, reforçado por um aumento no número de viagens internacionais (melhoria do cambio), e estimulada por novelas de grande penetração na sociedade, tem levado a uma preocupação maior com elegância, gostos mais sofisticados, gerando novos padrões de consumo. (GIMENO, 2010, p.06)
\end{abstract}

Os consumidores estão atualizados sabendo o que vão exigir na hora das compras, verificando qualidade, sendo este o ponto primordial a ser atingido, pois sem ele perde-se demanda, perdendo os clientes para outros estabelecimentos que valorizam os produtos e os serviços.

Dessa forma com as exigências dos consumidores precisa-se por parte das organizações de um alinhamento estratégico dando suporte aos colaboradores que têm contato direto com os clientes, este alinhamento só é possível com o esforço conjunto dos setores englobando a área de marketing e de vendas tendo como meta a maximização da percepção de valor do comprador ou usuários de bens e serviços.

\title{
Poder de consumo
}

Nos próximos anos as empresas irão se deparar ainda mais com mudanças, os clientes estão consumindo mais devido à valorização da qualidade de vida, onde a população está em busca constantemente de tecnologias inovadoras, valendo destacar a elevação do poder aquisitivo da população brasileira, considerando os bons indicadores da economia.

Segundo a visão de Peres (2012), o consumismo vem se intensificando no decorrer dos anos, tendo inicio nos séculos anteriores com o surgimento do regime capitalista.

Sendo assim, as empresas tiveram que oferecer novidades para a sociedade, inovando seus conceitos, aplicando novas tecnologias e se atualizando cada vez mais para oferecer o que os consumidores procuram.

Na revolução digital muito dos consumidores tiveram acesso exageradamente às informações que são expostas em pouco tempo, o que promoveu um elevado grau de exigência no momento da compra. O consumidor de século XXI é diferente dos antigos, pois, são mais exigentes com o mercado, comparam qualidade, preço entre outros fatores. 
Contudo de acordo com Ribeiro (2012):

Assim que os recursos foram ficando progressivamente disponíveis (com o aumento dos rendimentos e o conseqüente aumento da oferta), o consumo subiu num ápice ao pódio de prioridades da vida social, [...].(RIBEIRO, 2012, p.03)

Dessa forma, com o aumento do poder do consumo, muitos começaram a intensificar as compras e em consequiência a oferta aumenta. Sendo assim o desejo de adquirir determinado produto ou serviço, muitas vezes é motivado por razões socioculturais.

Contudo Granato e Pereira (2011) citam fatores que influenciam o consumo como a motivação, personalidade e percepção do consumidor, sendo importante a equipe de venda direta se preocupar com esses fatores observando qual fator influencia o consumidor naquele momento.

Observa-se que para estes autores os indivíduos se encontram em classes sociais diferentes compostas por pessoas com mesmos valores onde têm interesses comuns e apresentam comportamentos semelhantes.

Sendo assim, o indivíduo procura uma diferenciação à frente da sociedade buscando uma boa maneira de expor sua individualidade perante uma sociedade cada vez mais massificada, é por isso que se encontram muitas marcas de produtos e serviços buscando atingir essa individualidade tendo tendência cada vez maior para criação de produtos exclusivos, personalizados ou até mesmo customizados pelo próprio consumidor.

\section{Conceito de Atendimento}

Atendimento segundo Nardi (2010) é o ato de vender algum produto ou serviço, ocorrendo na maioria das vezes entre duas pessoas. A vitrine da empresa é o seu atendimento, fazendo com que os clientes confiem no estabelecimento sentindo-se seguros com os serviços prestados.

Dessa forma, a clientela voltará e em contra partida realizará propaganda para as pessoas que conhecem indicando a empresa. Observa-se que o atendimento é um ponto importante em uma organização. Sendo assim as empresas têm que se preocupar com esse aspecto, podendo até reestruturar outros setores, mais sem um atendimento de qualidade a empresa não crescerá.

Sendo assim, Carvalho (2010) afirma que uma pessoa ficando satisfeita com o atendimento de uma determinada empresa tem uma forte tendência de contar para os amigos e parentes o que ela vivenciou. Da mesma forma se ela ficar insatisfeita, ela irá seguramente contar para todos a sua experiência. 
Sabe-se então que atender o cliente com delicadeza é ideal, pois eles são os alicerces das organizações. Tendo em mente esse conceito muitas organizações procuram fazer com que os clientes tenham momentos prazerosos na hora da compra, fazendo de tudo para prestar serviço de qualidade satisfazendo o consumidor.

Um atendimento realizado com eficácia trás grandes resultados para as organizações, pois tudo começa na hora das vendas, sendo este um canal de comunicação com a empresa. Com isso os empresários devem ter um bom relacionamento com os funcionários que têm contato direto com os clientes, sabendo suas exigências e melhorando os resultados.

No entanto segundo Persona (2012) as empresas estão em constante mudança trazendo inovações no atendimento, acontecendo resultados positivos para a organização. As organizações precisam posicionar o produto no mercado, mas corre o risco de não adequar cuidadosamente os serviços. Contudo uma mudança na organização sempre é complexa, pois sempre existem aqueles que resistem aos novos conceitos e aplicações.

O mesmo autor afirma que uma mudança só vai trazer recompensas se envolver todos os setores, fazendo uma corrente, um ajudando o outro, aplicando o que foi aprendido nos treinamentos.

Contudo Trotta (2012) afirma que com um ótimo atendimento acontecem melhorias na organização como, por exemplo, o marketing terá um custo mais baixo, pois clientes satisfeitos já são um canal de divulgação da empresa, fortalecendo por consequência á marca do negócio.

\section{Qualidade do atendimento}

Vive-se num ambiente acirrado cheio de concorrentes, sendo assim precisa-se conceder muita importância ao atendimento ao cliente, pois, hoje eles exigem qualidade nos serviços prestados.

Dessa forma Nardi (2010) afirma que o atendimento está se tornando o ponto diferencial nas empresas, pois, sendo ineficaz o cliente fica insatisfeito. Para não cair nessa armadilha, é preciso treinar os funcionários para tratar os clientes com delicadeza, sabendo ouvi-los e podendo identificar os seus desejos para realizar dessa forma um serviço de qualidade fidelizando o consumidor.

Convém ressaltar que o autor ainda afirma que com o foco no cliente, atendendo-o de forma eficiente, fortalece a marca da empresa onde esta situação favorece o surgimento de novos clientes devido à propaganda que o consumidor satisfeito faz para outras pessoas. Um atendimento bem feito trás vários fatores psicológicos como segurança e confiança para continuar sempre consumindo.

Neste contexto, verifica-se que os funcionários precisam ter paciência e precisão na hora de aplicar as técnicas de atendimento para assim conquistar cada vez mais clientes. 


\section{Métodos e Técnicas de Atendimento}

Os métodos e as técnicas de atendimento são primordiais para exercer com credibilidade as vendas, pois os vendedores que não aplicam as técnicas tendem a perder para a concorrência sua clientela.

Segundo Buss (2010) atender bem o cliente já não é o bastante, é preciso atendê-lo de forma que este tenha todas as suas dúvidas resolvidas e que fique satisfeito para que retorne ao local sempre que houver necessidade.

Afirma-se ainda que a arte de vender está presente no nosso dia-a-dia, sendo preciso apenas reformular os conceitos e criar novas técnicas, pois, o mercado está em constante movimento. Precisase inovar para conseguir permanecer no mercado e ampliar mais ainda a atuação, conquistando novos clientes expandindo o negócio da melhor maneira.

Acredita-se que um bom atendimento é aquele que consegue vender determinado produto em dado momento, mas além de propiciar a venda, é necessário também conquistar os consumidores e isto não é uma tarefa fácil, pois, leva tempo para conquistar a credibilidade que os clientes precisam perceber.

\section{Métodos de atendimento}

Existem muitos métodos de atendimento que podem ser aplicados nas organizações para o aperfeiçoamento das relações entre clientes e vendedores.

Segundo Nadir (2010) os métodos utilizados são:

a) O conhecimento do produto comercializado: para se ter sucesso na empresa precisa-se conhecer o produto oferecido, pois os clientes precisam ter conhecimento se aquele item supre as suas necessidades. É necessário passar todos os detalhes e responder com precisão todas as perguntas do consumidor.

b) Ter intimidade com o cliente: a intimidade estabelece entre vendedor e cliente uma relação de confiança, onde é através dos argumentos que as informações sobre o produto e sua utilidade na vida do comprador são apresentadas, sendo preciso estabelecer limites para esta intimidade.

c) Surpreenda o seu cliente com alguma coisa que ele não está esperando: um vendedor que busca o sucesso precisa surpreender seu cliente, oferecendo aquilo que ele não espera e antecipando seus movimentos para realizar seus desejos antes que sejam solicitados.

d) Fazer o cliente se sentir importante: o vendedor deve fazer com que o cliente se sinta 
importante em todas as ocasiões e oportunidades, sendo função do empresário fazer o vendedor se sentir bem para que isto aconteça.

e) Ouvir o que eles têm a dizer sem interrupções: saber ouvir é uma condição primordial para se conseguir conquistar o cliente, é fundamental saber ouvir seus desejos satisfazendo-os da melhor maneira, interromper o que eles estão falando é um erro que muitos cometem. É necessário esperar que eles acabem para depois falar mostrando o que eles esperam para suprir suas necessidades.

f) Trazer soluções ao invés de pedir sempre desculpas: o profissional de vendas não pode trazer desculpas quando o cliente chega com alguma reclamação e sim mostrar soluções possíveis, escolhendo a melhor e a mais eficaz solução para aquele momento.

g) Ter humor na hora das vendas: ser simpático é um ponto fundamental que deve existir por parte do vendedor na hora da negociação, pois o cliente quer ser atendido com um sorriso divertido, mais sem muito exagero, pois existem limites na hora da negociação.

h) Ter competência e ser profissional: mostrar para o consumidor a competência de vender na hora da abordagem, sendo conhecedor do produto e das promoções que a empresa está oferecendo; conhecer o ponto forte e fraco do produto, sendo cordial e transmitindo uma realidade tangível de compra.

i) Fazer com que o cliente se sinta seguro e confiante: segurança e confiança são essenciais na hora da negociação com o consumidor. Precisa-se demonstrar argumentos seguros em relação o produto passando confiança e credibilidade para efetuarem a compra sem medo sabendo que tem garantia se algum problema aparecer.

j) Questionar o cliente sendo discreto: um funcionário dedicado às vendas precisa se organizar investigando os hábitos dos seus clientes e buscando indícios de seus consumos, interrogando com modéstia e perguntando sempre que necessário sem ofendê-los com discrição, pois, perguntar em um momento que não é propicio pode ser indelicado quebrando o laço de confiança e abalando a relação do consumidor com a organização, por isso a importância de ser discreto nas perguntas, sempre dando oportunidade ao consumidor de responder ou não.

Segundo o autor todos os métodos são importantes, mais o que prejudica em grau maior as empresas atuais é a falta de ouvir o que o cliente e também da incompetência do profissionalismo devido à inexistência de treinamentos adequados com os colaboradores. 


\section{Metodologia}

Inicialmente foi realizada uma pesquisa bibliográfica que segundo os autores Lakatos e Marconi (2010) estuda toda a bibliografia com a finalidade de colocar o pesquisador em contato com todos os materiais que falam do assunto estudado, onde se busca informações para ajudar no conhecimento sobre o tema abordado. Sendo assim esta pesquisa buscou em livros e sites informações essenciais onde foram elaborados fichamentos com o intuito de fundamentar este trabalho. Em seguida foi realizado o estudo de caso em apenas uma das filiais da empresa.

De acordo com Severino (2009), estudo de caso é a pesquisa concentrada na análise de um caso em particular onde é representativo, sendo que a coleta de dados e suas análises acontecem da mesma forma que na pesquisa de campo, em geral.

A pesquisa tem caráter investigatório, quantitativo, com aplicação de 2 modelos de questionários com 8 perguntas para os funcionários e 12 perguntas para os clientes. A amostra é composta de 50 clientes e 10 funcionários de uma empresa, localizada na cidade de Crato-CE.

Optou-se pelo questionário por ser esta a ferramenta que segundo os autores Lakatos e Marconi (2010) contribui para a formulação de perguntas ordenadas que possam ser respondidas sem a presença do entrevistador, sendo esta a forma mais adequada de coletar os dados que em seguida foram analisados.

\section{Objeto de Estudo}

A empresa foi fundada em 22 de setembro de 1998, funcionando em um pequeno prédio situado no centro de Juazeiro do Norte-CE, com poucas mercadorias e apenas um funcionário. Sua prioridade inicial foi à linha de livros didáticos e material escolar em geral. A partir do ano 2002, começou a expandir o seu trabalho externo em outras cidades da região, divulgando os seus produtos e participando de licitações públicas.

Em 2003 firmou parceria com a Editora FTD, filial de Fortaleza-CE, com o objetivo de auxiliar na divulgação dos produtos desta editora na região do cariri, valendo destacar que hoje a empresa mantém uma sala de atendimento ao professor totalmente confortável e com profissionais treinados para atender cada vez melhor.

No início do ano de 2004 foram incluídos no segmento de vendas novos produtos como: artigos para artesanato, fantoches, material esportivo e brinquedos pedagógicos em geral. Hoje são três lojas e mais de 22 funcionários envolvidos nas atividades do empreendimento. 
A missão da empresa é contribuir para o desenvolvimento e qualidade de vida das pessoas, através do apoio ao processo educacional, o objetivo da empresa é ser a primeira papelaria e livraria no interior do Ceará com solidez e envolvida em causa social.

O estudo foi realizado na unidade localizada no município do Crato-Ce, sendo que a escolha foi motivada pela facilidade na coleta dos dados.

\section{Análise de Dados}

\subsection{Pesquisa realizada com funcionários}

Inicialmente buscou-se investigar sobre o perfil dos colaboradores da empresa, tendo como ponto de partida a identificação da quantidade de homens e mulheres que trabalham na unidade analisada, como apresentado no gráfico 1 :

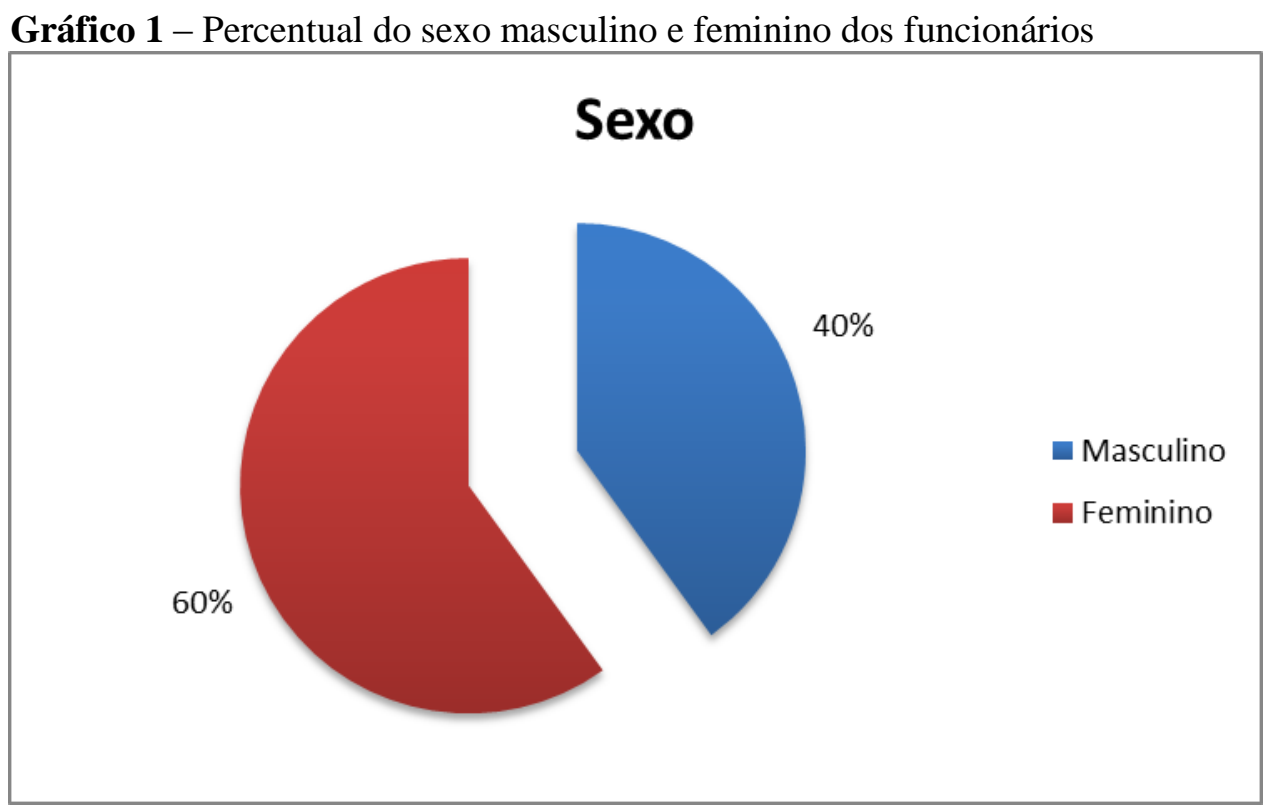

Fonte: Autor (2014).

Sendo assim, observa-se no gráfico 1 que na empresa estudada existem mais mulheres contratadas do que homens, o que evidencia a suposta valorização desse perfil.

Também, buscou-se analisar a faixa etária dos colaboradores, tendo sido identificado o seguinte resultado: 
Gráfico 2 - Percentual da faixa etária dos funcionários

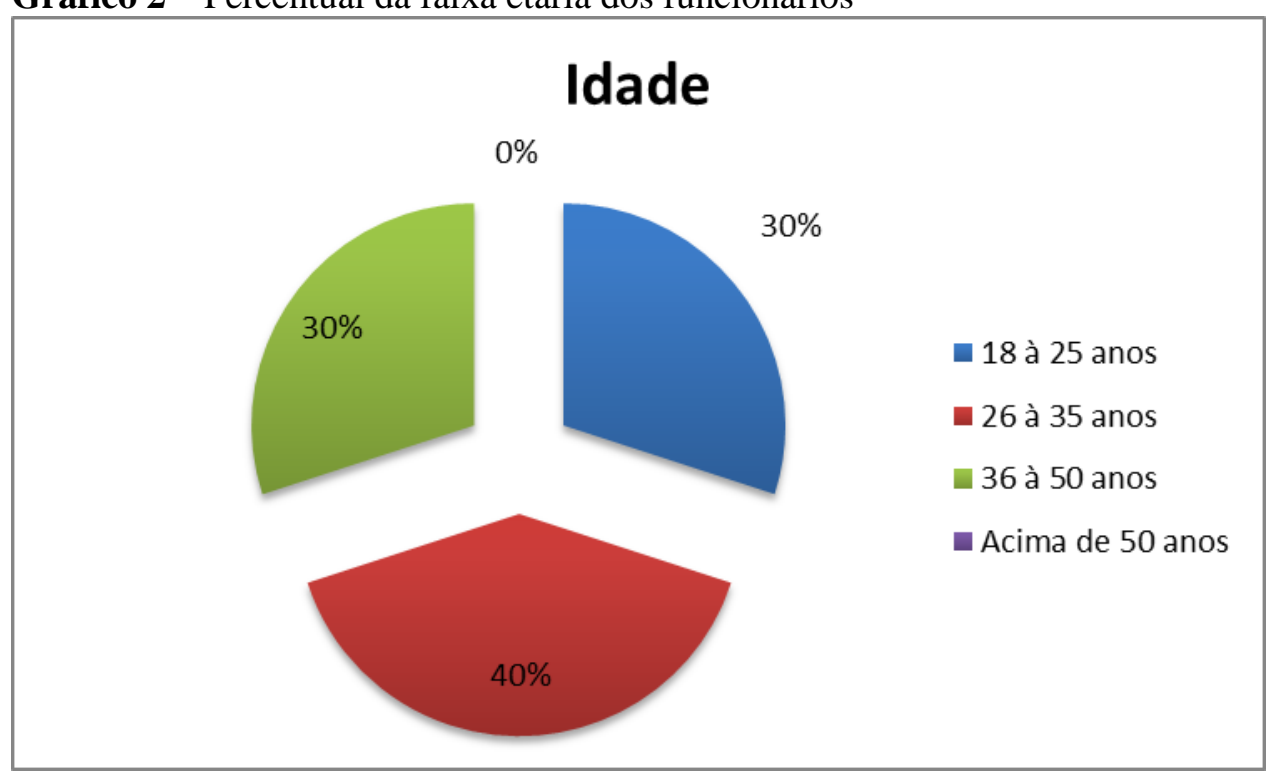

Fonte: Autor (2014).

Dessa forma em relação à faixa etária, pode-se observar no gráfico 2 que a empresa é composta em maior quantidade por pessoas jovens entre 18 a 25 anos e 26 a 35 anos, entende-se então que a empresa estudada prefere pessoas novas, devido à rapidez das transformações, sendo elas eficazes na adaptação.

Analisou-se o estado civil dos colaboradores onde foram identificados os seguintes resultados:

Gráfico 3 - Percentual do estado Civil dos funcionários

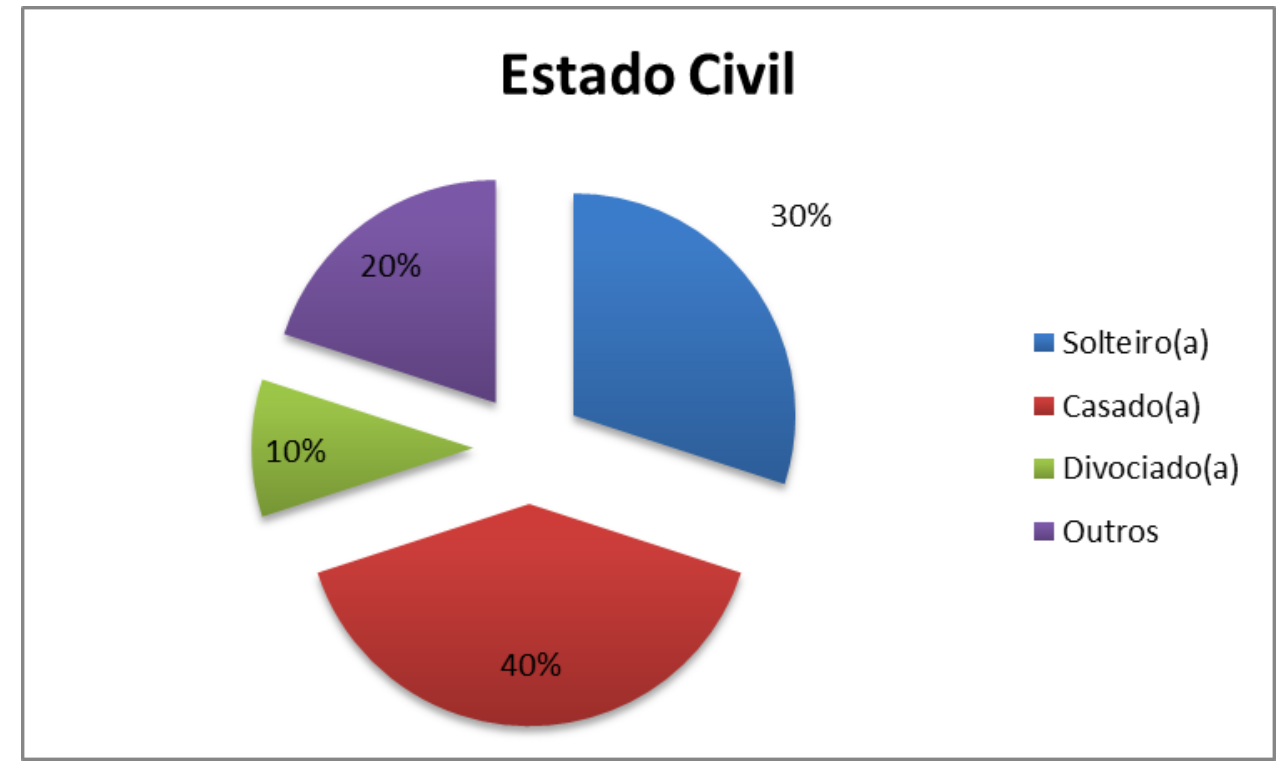

Fonte: Autor (2014). 
Observa-se com a pesquisa que a maioria dos funcionários são casados. Leva-se em conta também o percentual de funcionários solteiros. Entende-se que o gestor valoriza o tipo de perfil solteiro pela disponibilidade de tempo e flexibilidade de horários que apresentam e os casados devido à experiência de vida e de trabalho sendo mais maduro nos pensamentos e no modo de agir.

Uma vez identificando às características básicas dos colaboradores a pesquisa propôs a indagação sobre há quanto tempo trabalham na empresa estudada. O gráfico 4 ilustra essa questão:

Gráfico 4 - Quantidade de tempo na empresa

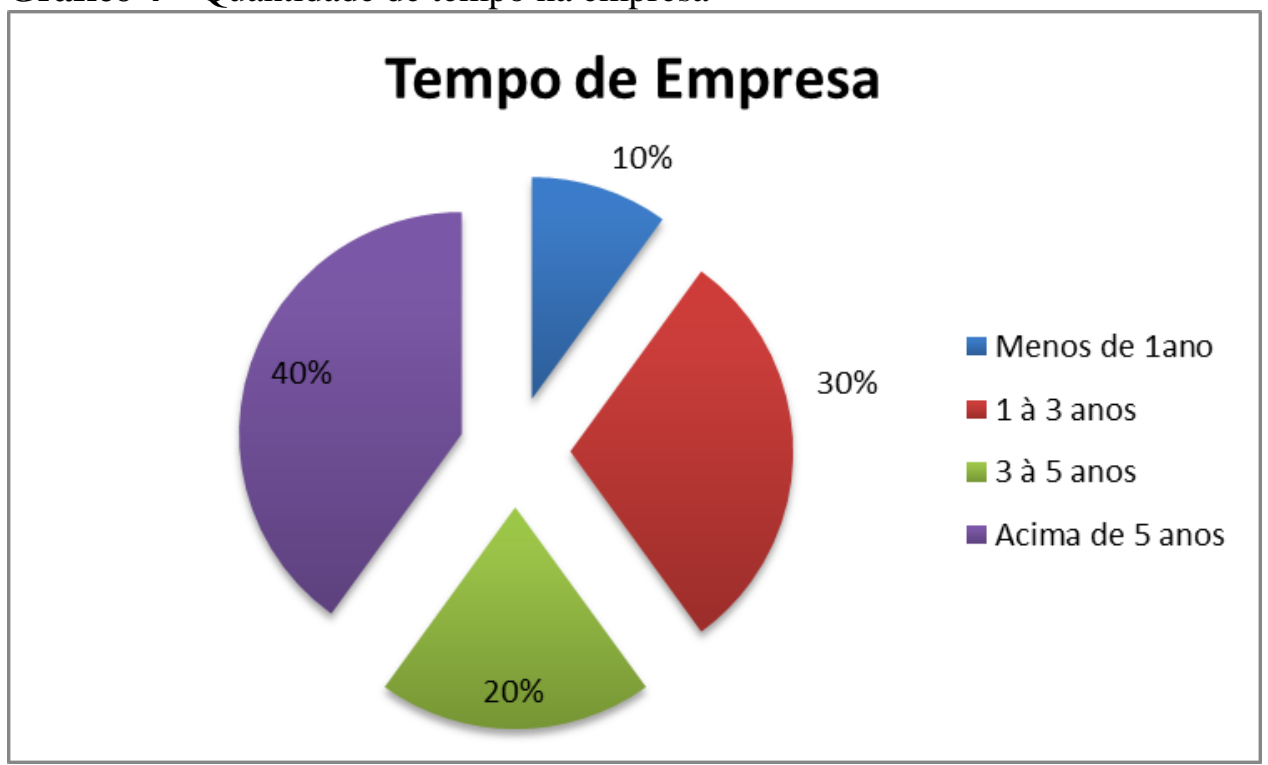

Fonte: Autor (2014).

Observa-se na figura acima que $40 \%$ dos funcionários possui acima de 5 anos de empresa, $10 \%$ dos colaboradores trabalham menos de 1 ano, $30 \%$ entre 1 a 3 anos e 205 entre 3 a 5 anos.

Em seguida, foi analisado se os colaboradores têm treinamentos por parte da empresa. 
Gráfico 5 - Fornecimento de treinamento relacionado com atendimento

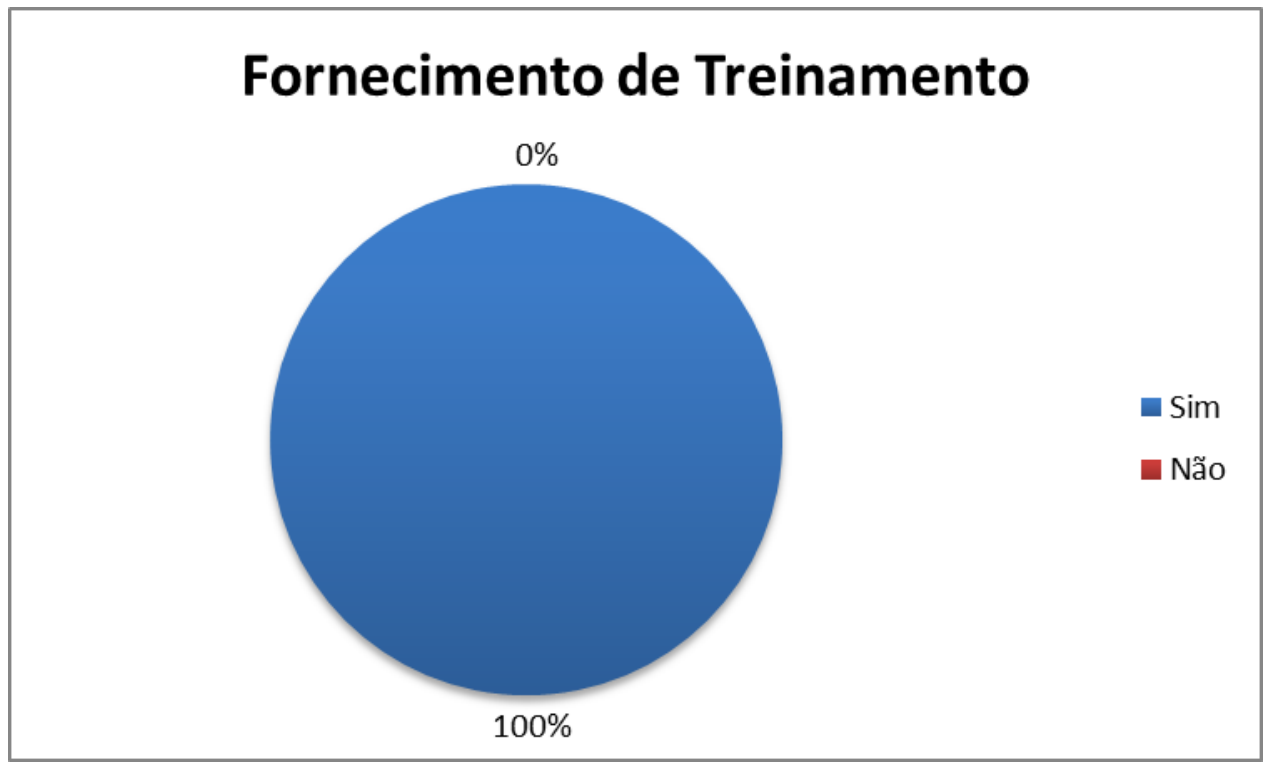

Fonte: Autor (2014).

Observa-se que a equipe de colaboradores da organização pesquisada participa de treinamentos para melhorar o atendimento, pois $100 \%$ dos funcionários afirmaram que treinamentos são fornecidos, o que de fato evidencia a atenção da direção sobre o assunto.

Nesse contexto Nardi (2010) afirma que o treinamento é essencial para o desenvolvimento de qualquer planejamento onde vislumbra o cliente como foco das ações, sendo provido de treinamento, pode-se esperar uma melhora no planejamento capacitando os elementos que participam de alguma maneira da relação com o cliente, preparando os vendedores para um relacionamento duradouro com cliente.

Dessa forma Wellington (2011) completa afirmando que a excelência no atendimento não acontece por si só, precisa-se criar um ambiente propício para boas vendas através de treinamento.

$\mathrm{Na}$ sequência foram pesquisadas quais as técnicas que os vendedores utilizam, sendo estas importantes para a concretização do objetivo que é realizar um maior número de vendas aumentando a receita da empresa. 
Gráfico 6 - Técnicas utilizadas pelos funcionários da empresa

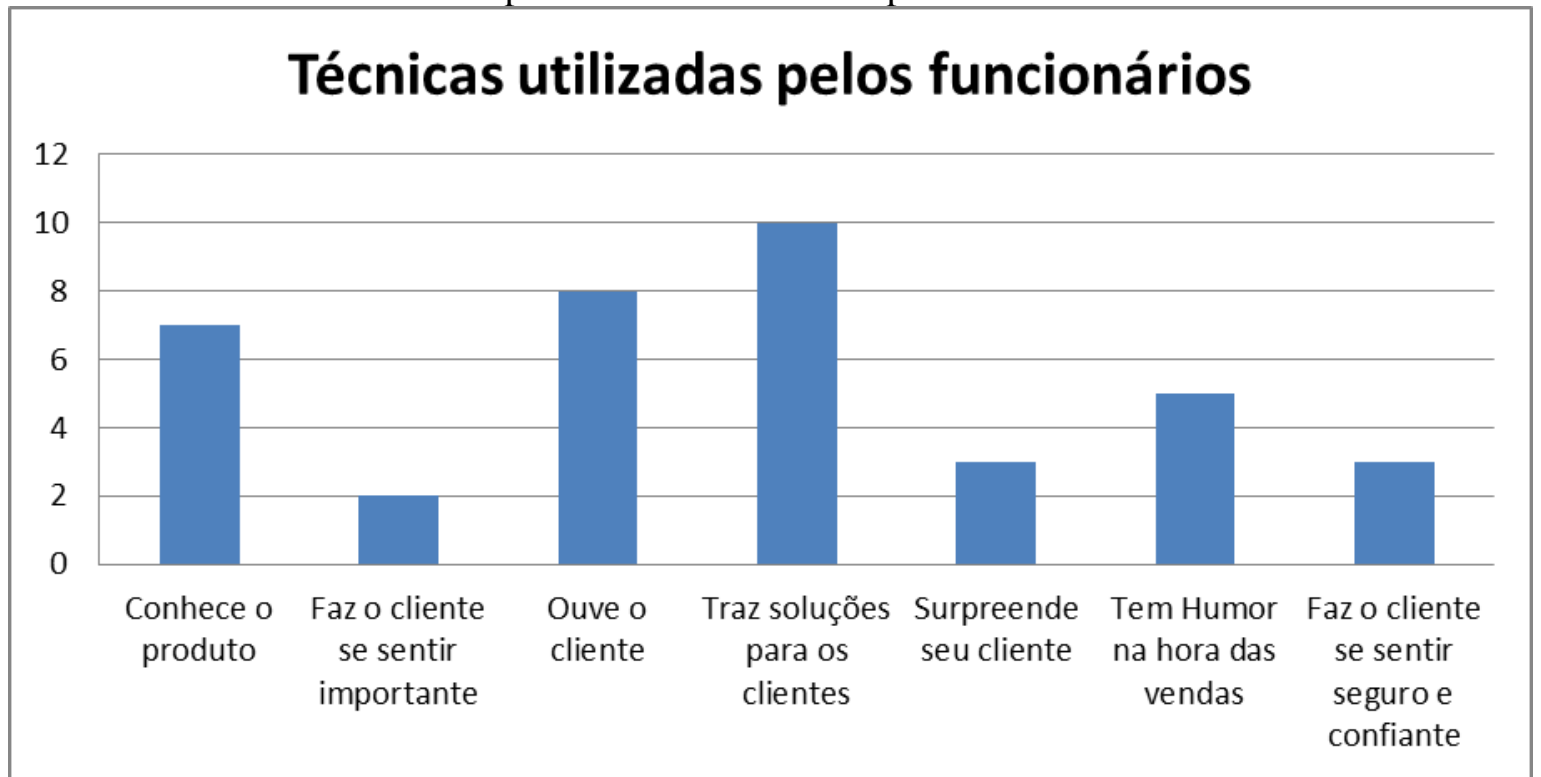

Fonte: Autor (2014).

Ao serem indagados sobre as técnicas aplicadas, pode-se observar que os funcionários marcaram mais de uma reposta, pois a pergunta é de multipla escolha. Sendo assim, no gráfico a cima indentifica-se que 7 funcionários responderam que conhecem o produto que estão vendendo, 2 funcionários falaram que utilizam a técnica de fazer o cliente se sentir importante, 8 ouvem o cliente atentamente, 10 trazem soluções para os clientes satisfazendo o consumidor, 3 surpreendem o cliente com alguma situação que ele não espera sendo o fator surpresa, 5 colaboradores têm humor nas hora das vendas, e por ultimo 3 funcionários afirmaram que fazem o cliente se sentir seguro e confiante, sendo visto de importancia para a negociação fluir facilmente.

Dessa forma, pode-se observar que com as respostas dos funcionários todos têm iniciativa para solucionar os problemas dos consumidores, aprimorando o atendimento com respostas rápidas para as dúvidas.

Observa-se que os funcionários da empresa identificam que as técnicas utilizadas por eles surtem efeito, pois $100 \%$ dos entrevisatados afirmaram na sétima pergunta que reconhecem que os efeitos das técnicas são positivos, colaborando para o alcance das metas e para a sustentabilidade do negócio.

O entendimento da nescessidade dos clientes é importante, pois, nota-se que se atendido bem, o consumidor tende a voltar e realizar novas compras. O gráfico 7 demonstra a opinião dos vendedores sobre os motivos que levam a eles informarem que as técnicas utilizadas promovem um impacto positivo para empresa estudada. 
Gráfico 7 - Os motivos das técnicas surtirem efeito

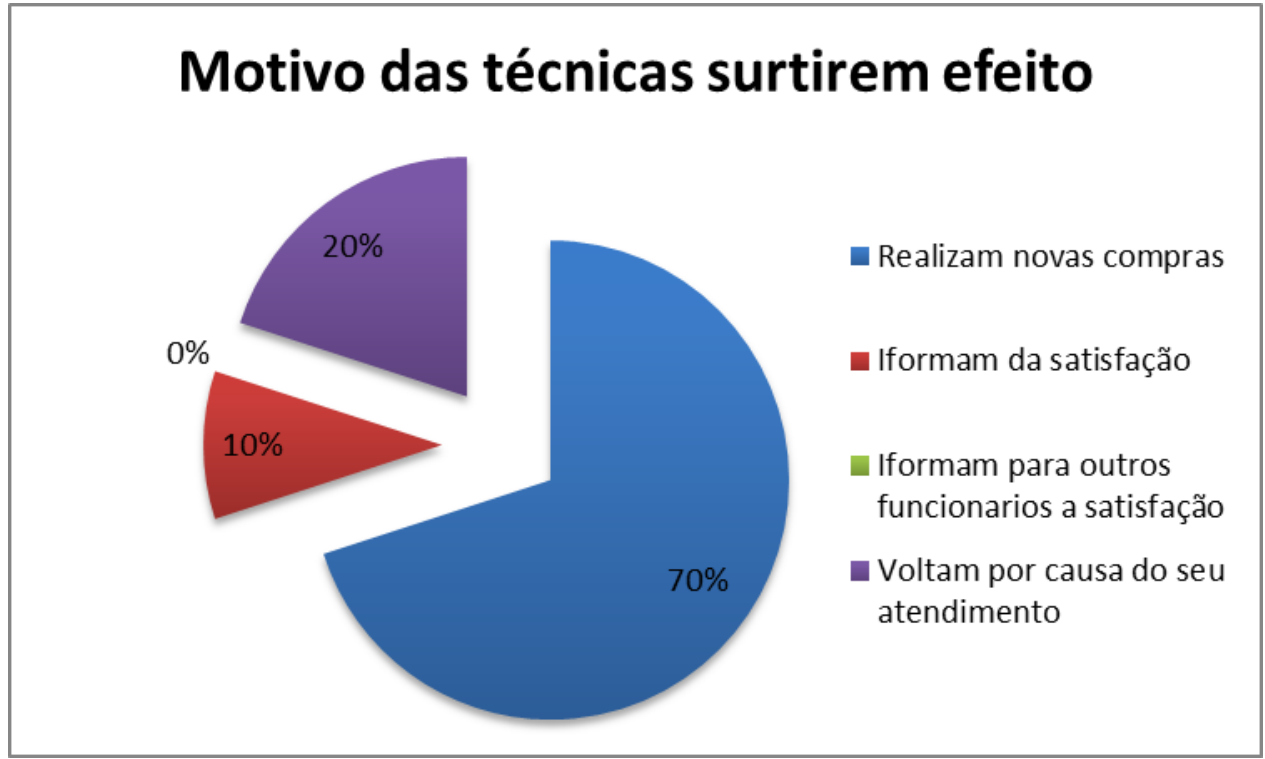

Fonte: Autor (2014).

Sendo assim, 70\% dos colaboradores afirmaram que sabem que as técnicas surtem efeito por que os consumidores realizam novas compras. Sendo assim, diante do posicionamento dos funcionários, observa-se que o atendimento ao cliente é considerado uma temática importante para a gestão da empresa, uma vez que existem treinamentos e os colaboradores sabem reconhecer quais são as técnicas que utilizam para vender.

Seundo Nardi (2010) todas as ferramentas são importantes em um cenário real de mercado e competitividade.

Dessa forma, observa-se que as técnicas aplicadas pelos vendedores surtem efeito devido ao retorno dos consumidores para fazer novas compras, conclui-se que técnicas aplicadas de forma eficiente tem um retorno nas vendas.

Na aplicação do questionário aos clientes da empresa pesquisada foram observados o perfil e a percepção de atendimento. É o que segue na seção 6.2.

\section{Clientes}

Em seguida buscou-se investigar sobre o perfil dos clientes da empresa e analisar sob o ponto de vista dos mesmos como a empresa realiza o seu atendimento e se estão satisfeitos, tendo como ponto de partida a identificação da quantidade de homens e mulheres que compram na unidade analisada, inormação apresentada no gráfico 8: 
Gráfico 8 - Percentual do sexo masculino e feminino dos clientes

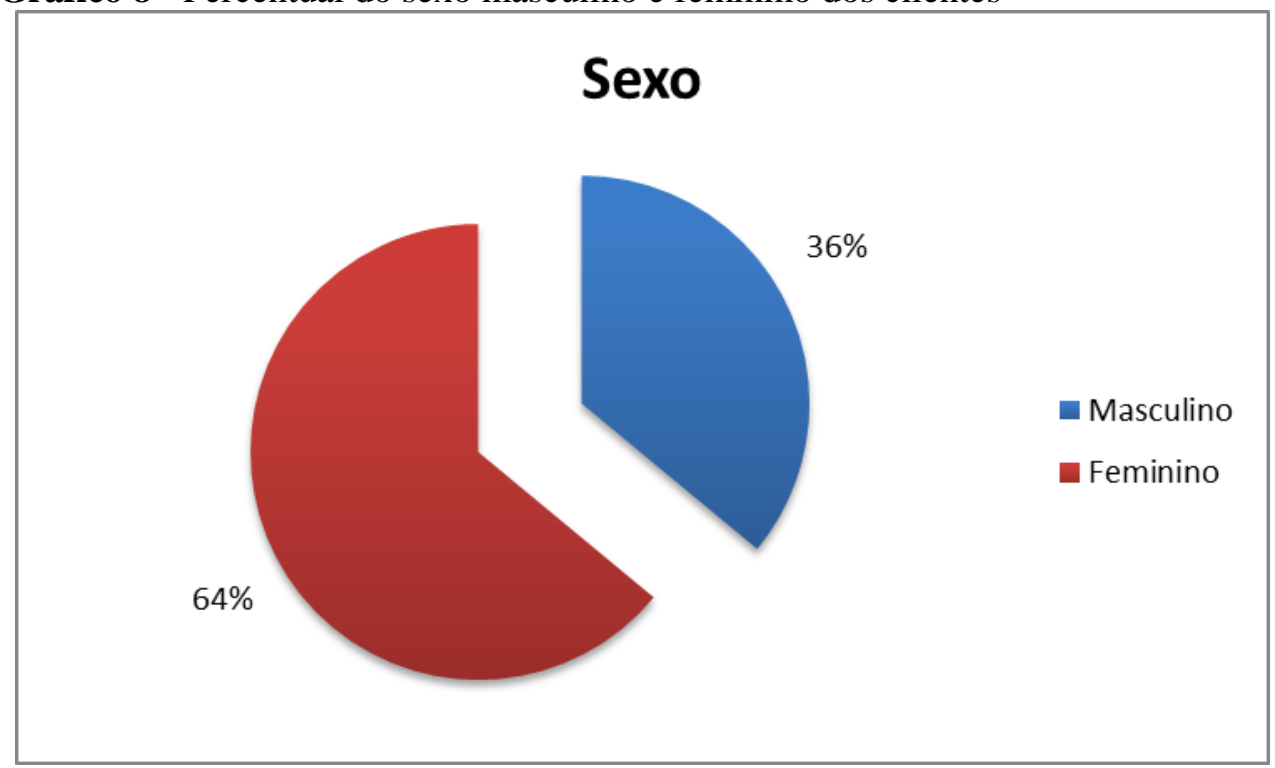

Fonte: Autor (2014).

Observa-se no gráfico acima que os consumidores do sexo feminino, $64 \%$ frequentam a livraria mais do que os homens, $36 \%$, sendo que muitas das consumidoras estavam acompanhados de seus filhos, realizando a compra para os mesmos.

Verificou-se o estado civil dos clientes, conforme resultado abaixo:

Gráfico 9 - Estado civil dos consumidores

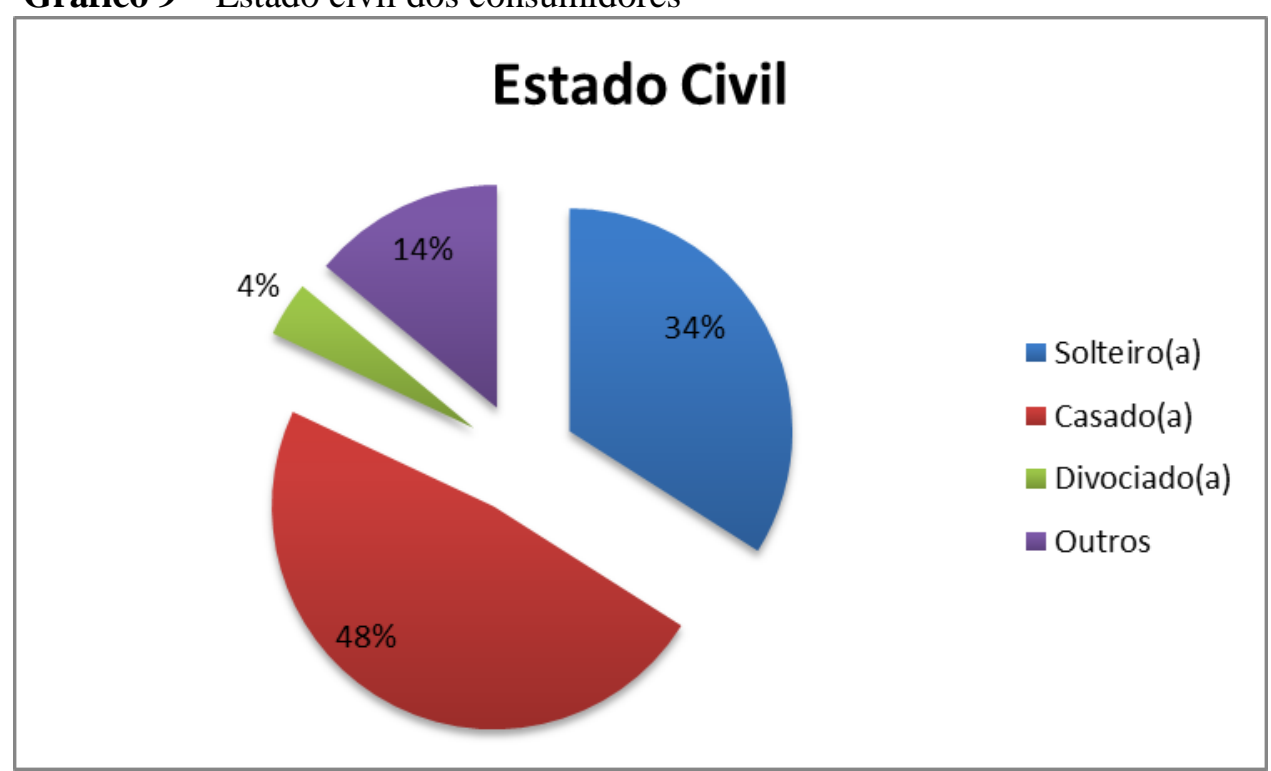

Fonte: Autor (2014).

Nota-se que a maioria dos consumidores que compram na livraria são casados. 
Em seguida foi verificada a idade dos clientes, conforme gráfico abaixo:

Gráfico 10 - Faixa etária dos consumidores

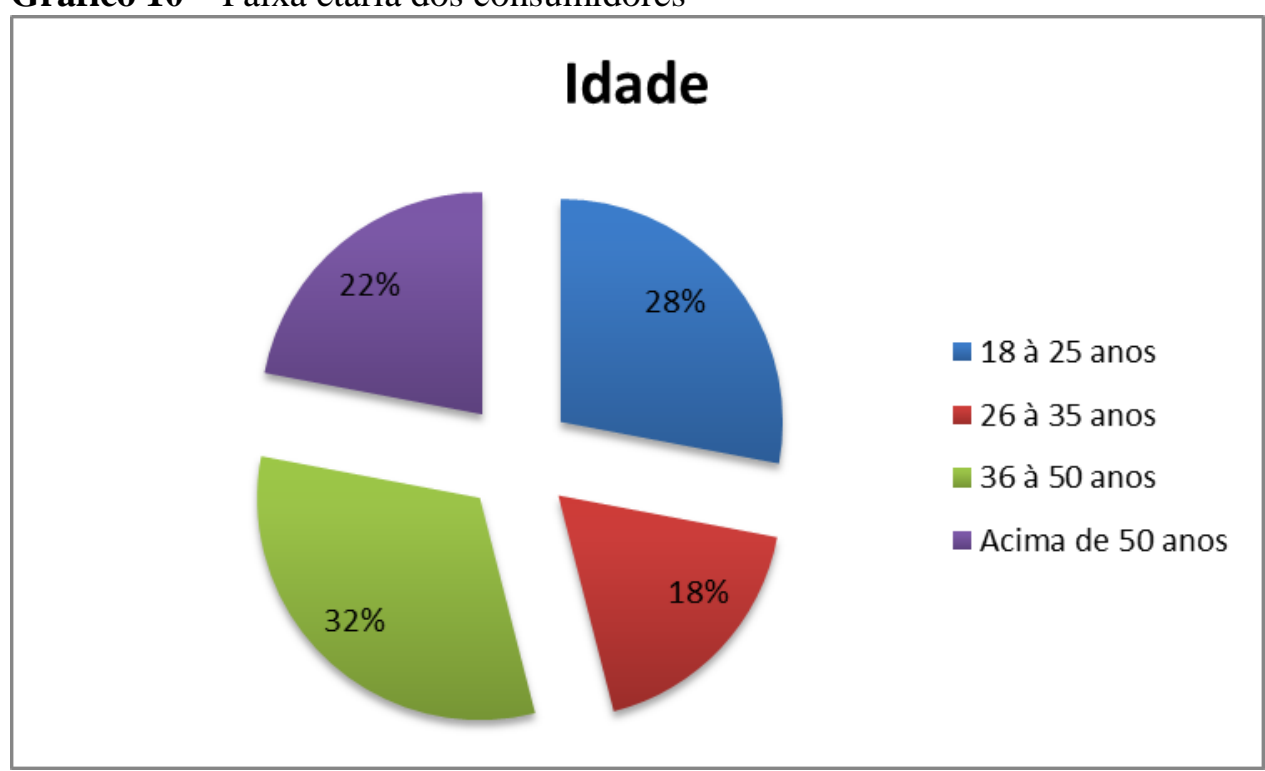

Fonte: Autor (2014).

Observa-se no gráfico 10 que a maior clientela encontra-se na faixa de 36 a 50 anos, pois de acordo com a pesquisa $32 \%$ dos clientes têm essa idade. Em seguida está a faixa de 18 a 25 anos com $28 \%$, sendo na maioria estudantes e trabalhadores que vão adquirir material escolar e de escritório, comprovando o foco que a livraria tem que seguir para atingir esse público.

$\mathrm{Na}$ sequiência foi questionada qual a renda mensal dos clientes tendo como resultado o gráfico 11.

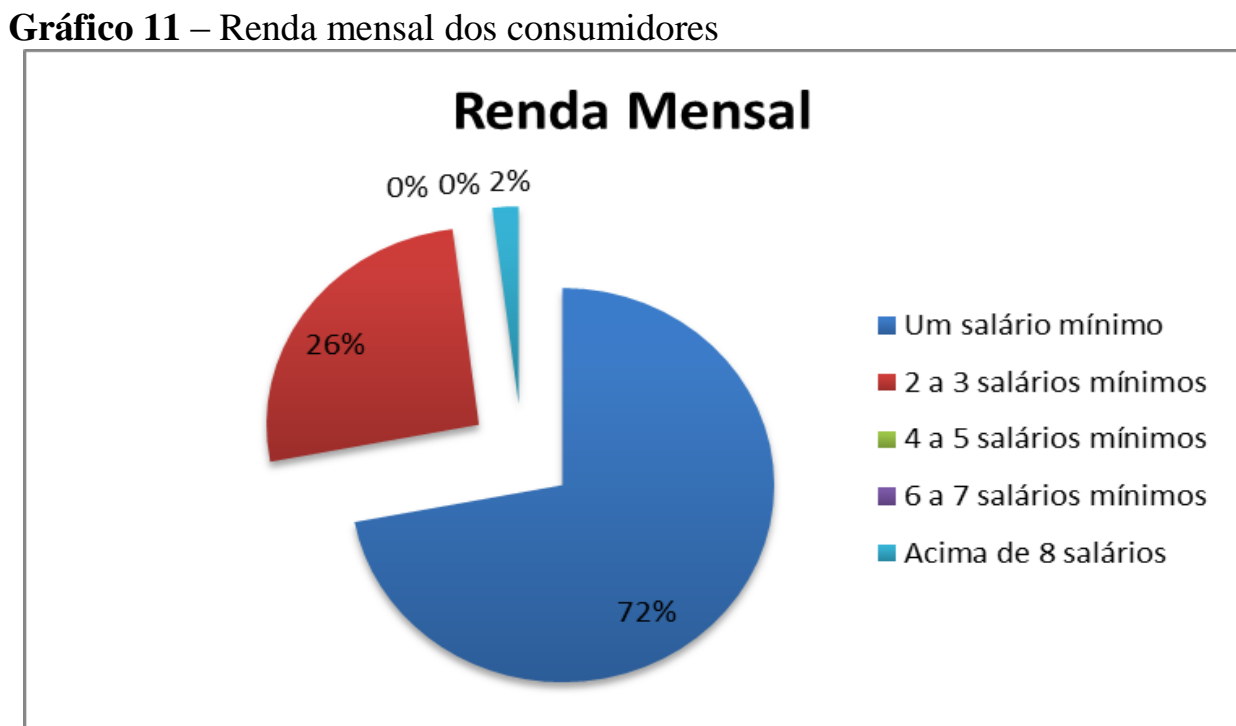

Fonte: Autor (2014). 
Demonstra-se que o maior percentual dos consumidores têm uma renda mensal de um salário mínimo. Foi questionado em seguida como é classificado o atendimento da empresa pesquisada, obtendo os segintes resultados no gráfico 12 .

Gráfico 12 - Classificação da qualidade do atendimento da empresa

\section{Qualidade do Atendimento}

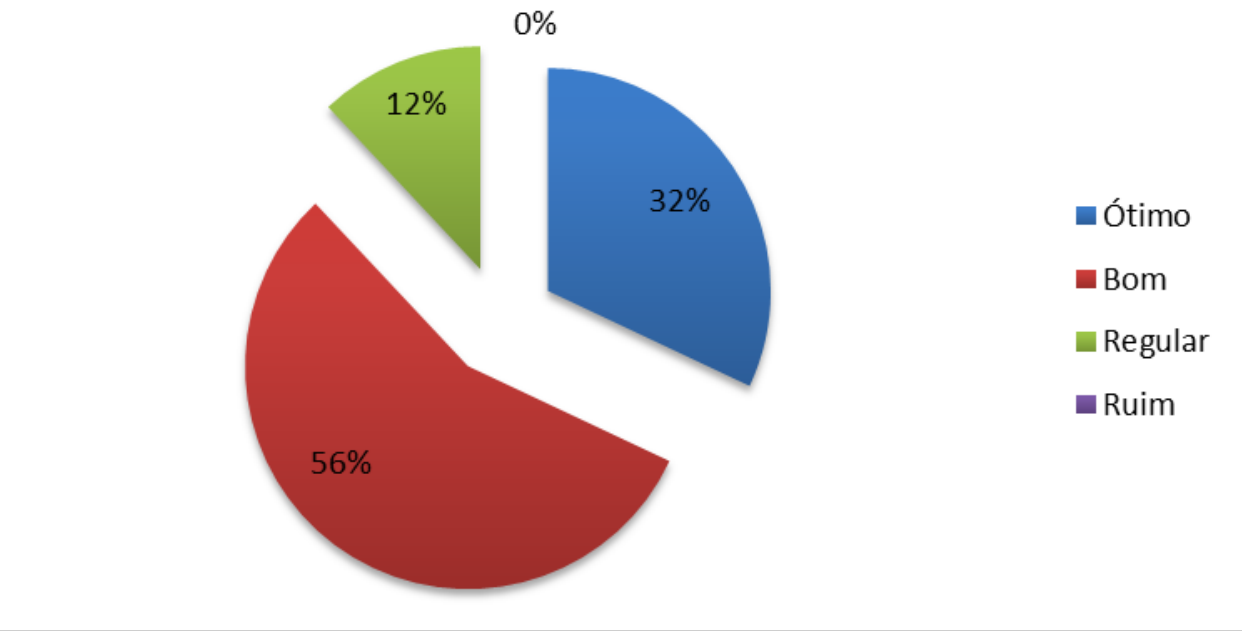

Fonte: Autor (2014).

A maioria dos entrevistados afirmou que a qualidade do atendimento é boa observa-se pelo gráfico que foram $56 \%$ evidenciando a existência de potencial de melhoria da área. Em seguida 32\% afirmaram que a qualidade é ótima. $12 \%$ registroram que é regular sendo este um potencial de clientes para ser trabalhado para tentativa de fidelização dos mesmos.

Sendo assim Wellington (2011) diz que a pessoa aprimoramentos no atendimento buscando a qualidade se tentar. Só fará melhorias continuas caso se preocupe com seu atendimento. Portando é trabalho do gestor criar um ambiente em que os integrantes da área de vendas sintam-se necessários, apoiados e valorizados como indivíduos.

O mesmo autor ainda afirma que se precisa criar um ambiente em que os funcionários possam ter um senso de orgulho pelo trabalho realizado, onde possam sentir que as ideias e sugestões são levadas em consideração, tendo um retorno, não só em relação a suas ideias que são aplicadas, mas também quando não são. O desenvolvimento pessoal e multiplicidade de habilidades são outros ingredientes vitais para as vendas.

Verificou-se na sequência se os vendedores repassam com clareza as informações para os consumidores, obtendo o seguinte resultado: 
Gráfico 13 - Informações passadas com clareza para os consumidores

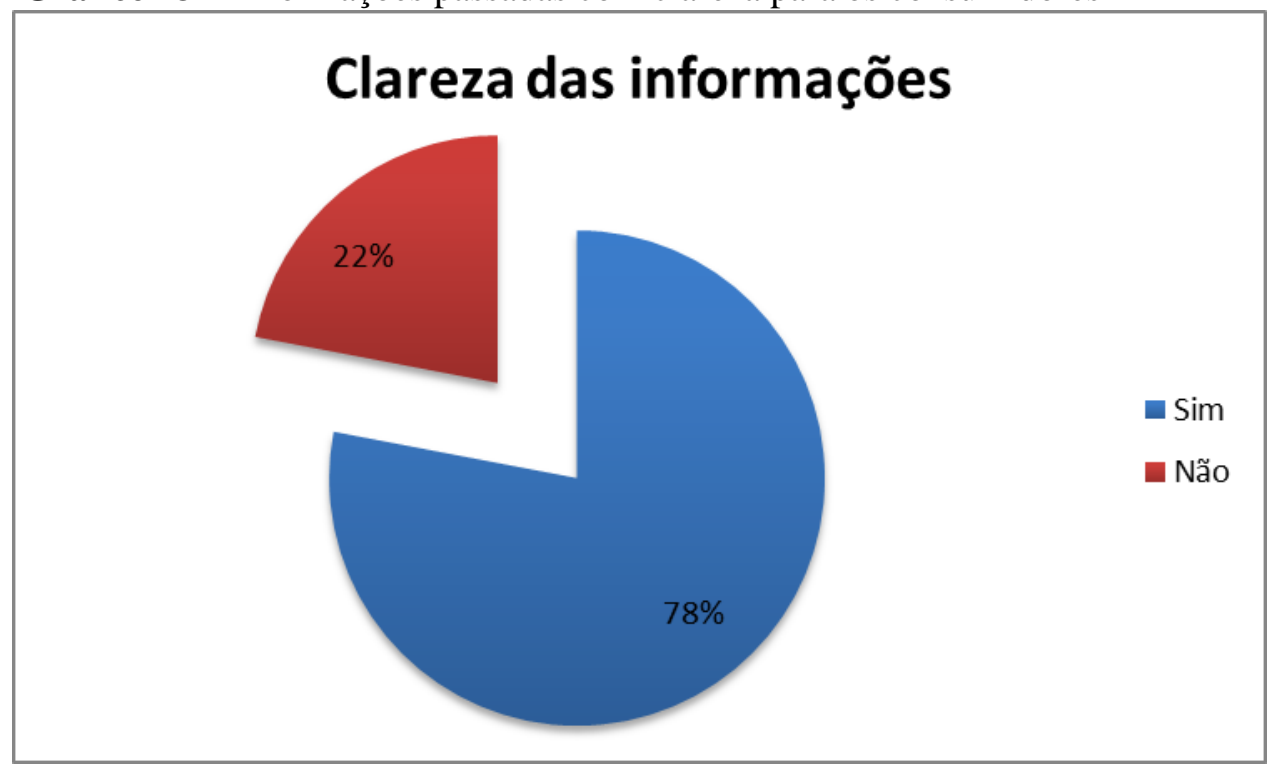

Fonte: Autor (2014).

Observa-se que a maioria dos atendentes passa as informações sobre o produto com clareza, ficando comprovado pela pesquisa com os consumidores que $78 \%$ afirma isto.

Em seguida buscou-se analisar se o funcionário atende demonstrando interesse em resolver as nescessidades dos consumidores, obtendo a seguinte resposta:

Gráfico 14 - Interesse em solucionar problemas dos consumidores

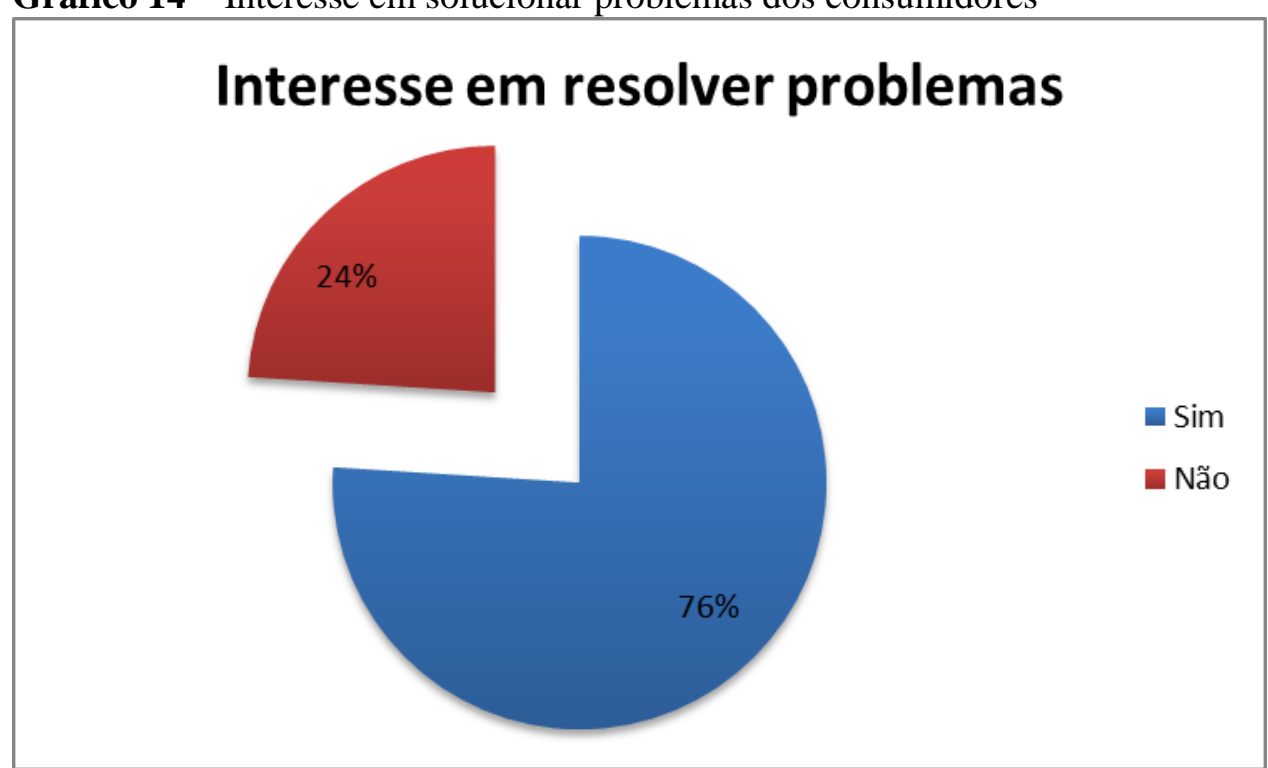

Fonte: Autor (2014). 
Nota-se que a maioria dos clientes está satisfeita com o interesse dos funcionários em resolver seus problemas, demonstrando que $76 \%$ pensam dessa forma.

A seguir, perguntou-se se o atentende ouviu adequadamente o desejo do cliente, sendo primordial para realização de uma venda, pois o vendedor precisa interpretar as informações passadas pelo consumidor. $\mathrm{O}$ resultado foi positivo.

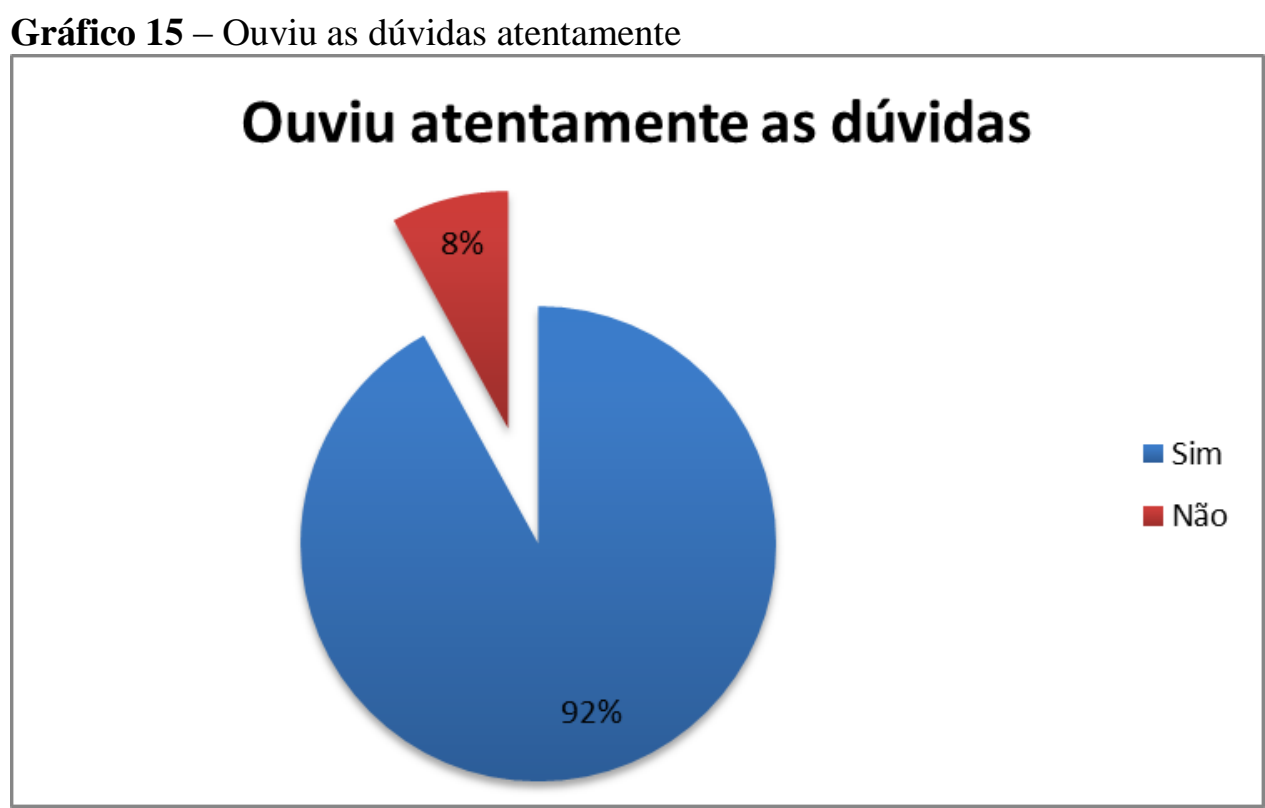

Fonte: Autor (2014)

Observa-se que a grande maioria dos consumidores entrevistados afirmaram que os atendentes ouviram de forma adequada os seus desejos. De acordo com o gráfico 16, $92 \%$ dos clientes confirmaram que foram atendidos e que os vendedores ouviram adequadamente os seus desejos, $8 \%$ afirmaram que os funcionários não ouviram de forma adequada, o que evidencia a necessidade de alinhamento deste aspecto com parte dos vendedores.

Segundo Nardi (2010) o vendedor que tem sucesso é aquele que estabelece contato visual e principalmente verbal com o seu cliente ininterruptamente, é nescessário o vendedor ser um bom ouvinte tendo paciência e atenção a disposição do cliente, portando primordialmente importante saber escutar o consumidor, reter e filtrar o que existe de importante nesse conhecimento informal, com a finalidade de revertê-lo ao favor do vendedor para vendas futuras.

O mesmo autor ainda afirma que se deve ter um cuidado especial em um diálogo entre vendedor e cliente sendo está uma conversa informal o cliente deve ser o foco principal onde se tem a preferencia para perguntar, exigir ou simplesmente falar, desabafar e rir. 
Em seguida, foi perguntado se os vendedores fizeram os cliente se sentirem importantes, segue o gráfico 16:

Gráfico 16 - O vendedor fez você se sentir imporatante

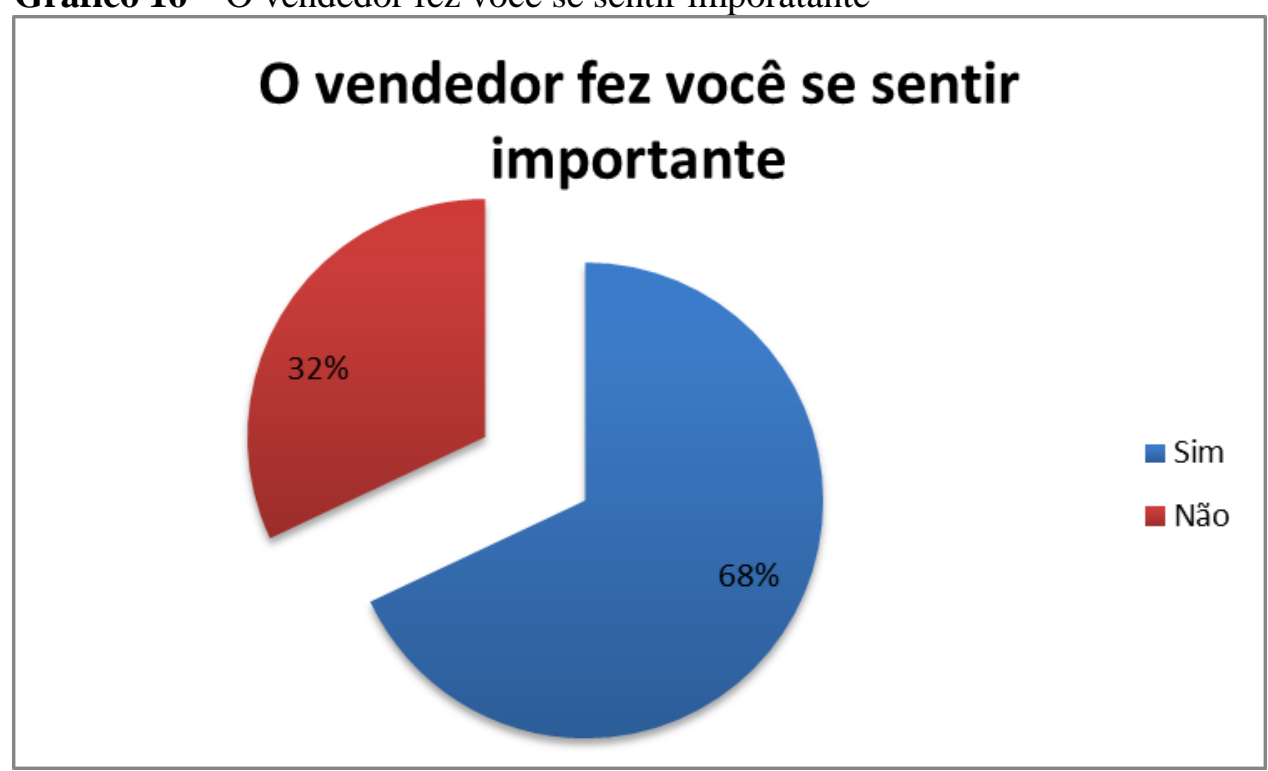

Fonte: Autor (2014).

No processo de atendimento, $68 \%$ dos clientes entrevistados se sentiu importante no momento da abordagem, em contrapartida, 32\% dos entrevistados não se sentiram importante na hora do atendimento. Muito embora a maioria tenha regitrado que se sentiu importante, evidencia-se a necessidade de adequação do comportamento de parte dos vendedores para que o percentual de $32 \%$ seja reduzido.

Questionando-se sobre a iniciativa dos vendedores em solucionar os problemas que surgem na área de vendas, obteve-se o gráfico 17:

Gráfico 17 - Solucionamento dos problemas pelos vendedores

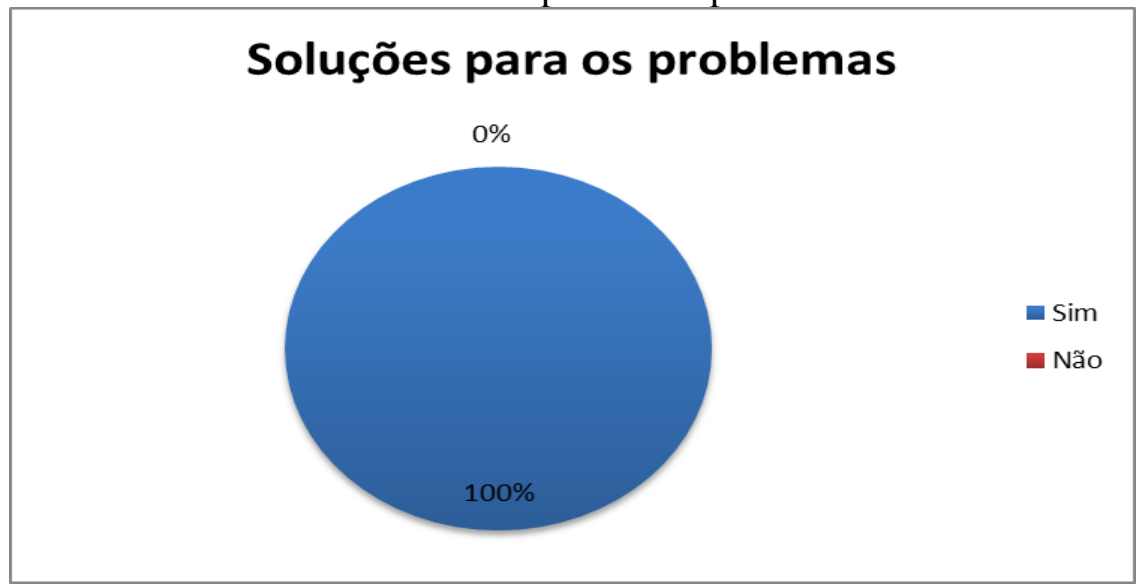

Fonte: Autor (2014) 
Nota-se que o solucionamento dos problemas está sendo satisfatório na empresa estudada, onde $100 \%$ das pessoas entrevistadas afirmaram que os atendentes solucionam os problemas recorrentes na área de vendas.

Em seguida, foi pesquisado entre os clientes se os funcionários conhecem o produto que estão vendendo, observa-se o gráfico 18:

Gráfico 18 - Conhecimento do produto vendido.

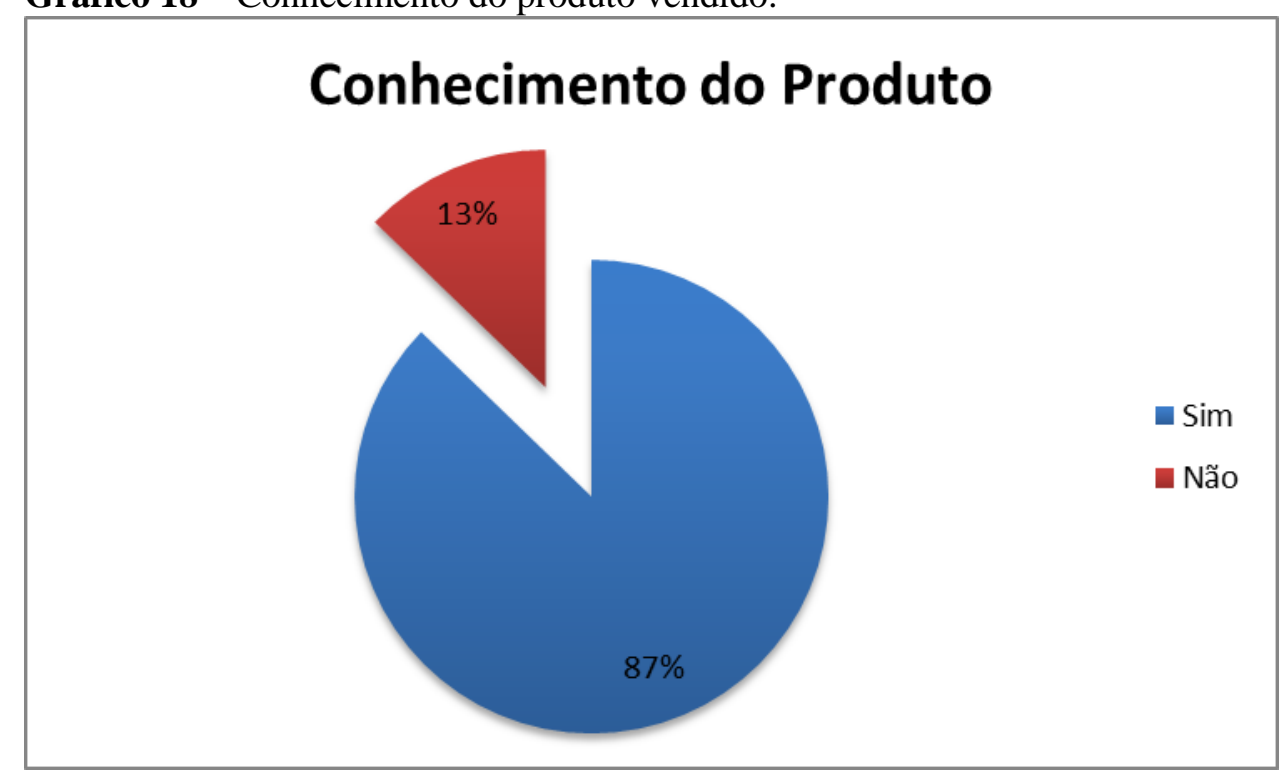

Fonte: Autor (2014).

No gráfico acima, verifica-se que $87 \%$ dos entrevistados reconhecem que os funcionários conhecem o produto vendido, sendo de importancia para facilitar as vendas já que os consumidores precisam de detalhes do produto.

Por fim, foi analisado se os funcionários atendem os consumidores com bom humor, analisase o resultado no gráfico 19: 
Gráfico 19 - Funcionários humorados na hora das vendas

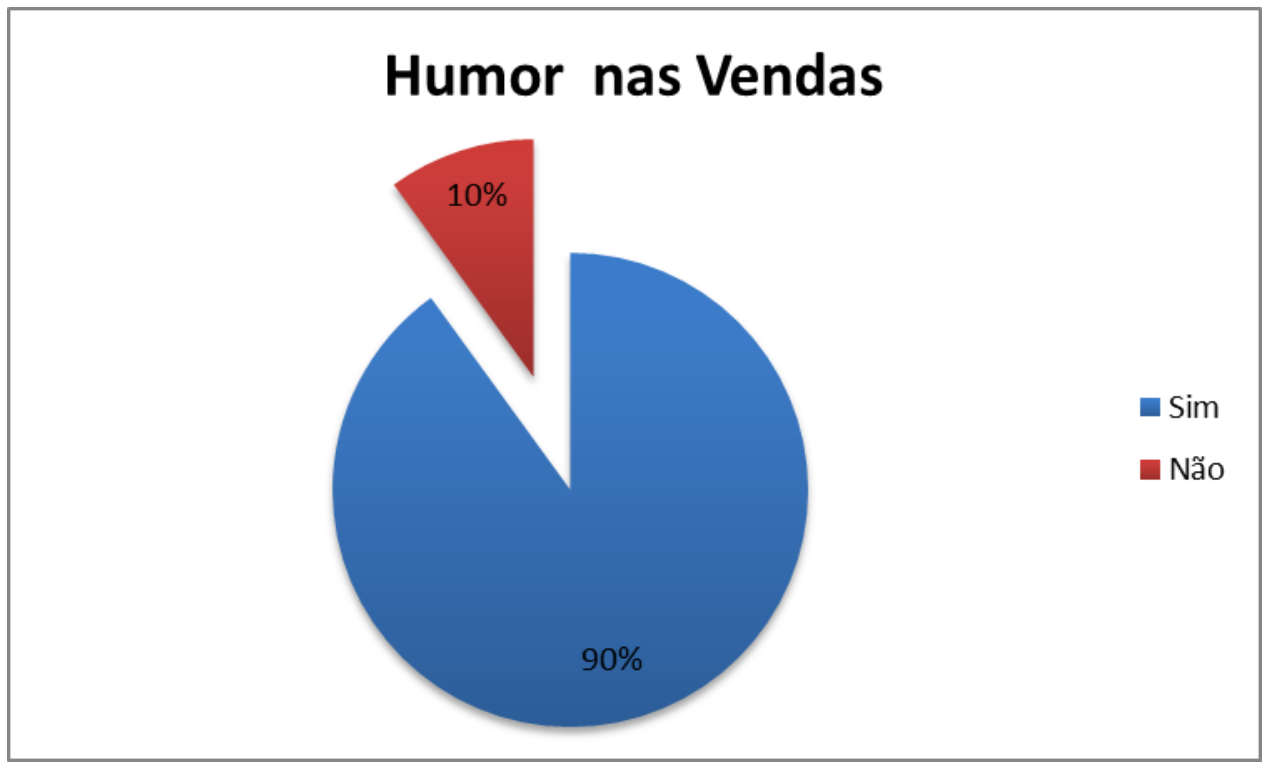

Fonte: Autor (2014).

Sorrir na hora das venda é de fundamental importância para uma empresa fidelizar os consumidores. A organização estudada treina seus funcionários para atender seus clientes de forma adequada com bom humor, sendo que $90 \%$ das respostas foram positivas.

\section{Análise funcionários $x$ clientes}

De acordo com a pesquisa realizada, observa-se que as respostas dos funcionários estão coerentes com as informações apresentadas pelos clientes, mais em contrapartida tem uma pequena porcentagem dos consumidores que reclamam do atendimento da empresa. Contudo a referida organização precisa estudar os resultados e aplicar técnicas mais eficientes de atendimento para eliminar essa pequena insatisfação por parte dos clientes.

Observa-se que as técnicas aplicadas atualmente pelos funcionários da empresa não satisfaz $100 \%$ da sua clientela, com os dados em mãos a empresa precisa solucionar o problema indo em busca de uma técnica que satisfaça os consumidores $100 \%$, sendo difícil, pois sabe-se que as técnicas sempre têm uma parcela de rejeição, com isso com a técnica escolhida e a habilidade do vendedor pode-se diminuir satisfatoriamente a pequena rejeição por parte dos consumidores.

Segundo a leitura do gráfico 06, os funcionários não aplicam todas as técnicas, sendo de importancia a aplicabilidade das mesmas. Os funcionários aplicando-as poderia diminuir o grau de insatisfação, pois haveria mais opções de agradar o consumidor, se uma técnica não funcionar, outra poderia suprir, pois pode-se aplica-las simultaneamente 
No entanto, encontra-se constatado através dos gráficos que a empresa oferece um atendimento adequado para vendas, sendo esta a percepção da grande maioria dos consumidores pesquisados, pois, a maior porcentagem foi de bons resultados. Nota-se que a empresa se preocupa com seus consumidores e treina seus funcionários para atendê-los da melhor maneira, pecando um pouco, pela falta da utilização de todas as técnicas pelos funcionários.

\section{Considerações Finais}

Este trabalho teve como objetivo alcançado conhecer e analisar as técnicas de atendimento de uma empresa situada no Crato - CE. Assim foi realizada uma pesquisa onde se observa que a organização treina seus colaboradores para utilização das técnicas, sendo estas, de grande importância para concretização das vendas. As técnicas utilizadas surtem efeito satisfatório sendo elas de fácil aplicabilidade, por exemplo, ter humor na hora das vendas, conhecer o produto que está vendendo para passar todos os detalhes dos mesmos, entre outras.

Estas técnicas observadas que são aplicadas na empresa satisfazem a clientela sendo de qualidade para conquistar os consumidores.

$\mathrm{O}$ atendimento é prioridade de uma organização, pois é nesse momento que o cliente entra em contato com a empresa. Para deixar uma boa impressão da empresa perante seu público, é necessário incluir o atendimento como prioridade precisa se organizar e colocar como prioridade um excelente atendimento, pois, se realizar com eficiência o consumidor se satisfaz e leva uma boa imagem da organização.

Observa-se que devido às técnicas aplicadas e a habilidade dos funcionários da empresa os consumidores retornam para fazer novas compras, dessa forma a eficácia e a eficiência dos funcionários são demonstradas nos gráficos do trabalho.

Nota-se que é simples aplicar técnicas de atendimento, mas há resistência por parte das organizações, principalmente dos seus funcionários, sendo difícil aplicar as técnicas devido ao medo das mudanças. Muito se vê as empresas tentando inovar colocando novidades dentro das organizações para chamar mais clientes, contudo seria importante o gestor se preocupar também com a área de vendas inovando com técnicas de atendimento e treinando seus funcionários, pois devido à globalização sempre ocorre novidades e os que não inovam ficam para trás. 


\section{Referências}

ALMEIDA, Ricardo Dantas; NOGUEIRA, Durval Lordelo. Era da Informação e a exclusão digital. Disponível em: http://www.cinform.ufba.br/iv anais/artigos/TEXTO15.HTML>. Acesso em: 13/jun/2014.

BUSS, Scheila; Grau de satisfação no atendimento ao público prestado por funcionário do setor de triagem da prefeitura municipal de Forquilhinha -SC. Disponível em:< http://repositorio.unesc.net/bitstream/handle/1/312/Scheila\%20Buss.pdf?sequence=1 $>$ Acesso em: $15 /$ jun/2014.

CARVALHO, Clotildes Madalli da Rocha. Qualidade no atendimento e satisfação do cliente: Um estudo de caso na empresa Espaço Inteligência Imobiliário em Feira de Santana - BA. Disponível em: http://www.uefs.br/portal/colegiados/administracao/menus/monagrafias/2010/qualidade> Acesso em: $14 /$ jun/2014.

FERNANDES, Walberto. Excelência no atendimento ao cliente. São Paulo: Schoba, 2010.

GRANATO, Lourenço Augusto Camargo; PEREIRA, Paula Fernanda Prado. Ainda existem consumidores fieis?. Disponível em: http://www.redalyc.org/articulo.oa?id=273419416002. Acesso em: $14 /$ jun/2014

GIMENO, Sergio Pita. Comportamento do Consumidor: Motivação do consumidor e percepção de consumo em particular no mercado de luxo. Disponível em: < http://www.fipen.edu.br/hermes1/index.php/hermes1/article/download/35/23>.Acesso em: $13 /$ jun/2014.

LAKATOS, Eva Maria; MARCONI, Marina de Andrade. Fundamentos de metodologia científica. São Paulo: Atlas, 2010.

MARQUES, Fábio. Guia prático na excelência em serviços: Como conquistar clientes, aumentar os lucros e viver melhor! São Paulo: Nobel, 2012.

NARDI, Sergio. Atendimento de sucesso: Entenda o cliente e venda mais. São Paulo: Novo Século, 2010.

PERES, Daniel Neve. O consumidor no controle: Os novos rumos da publicidade na sociedade de consumo pós-moderna. Disponível em: <http://revistaseletronicas.pucrs.br/ojs/index.php/graduacao/article/viewFile/3474/2731 >. Acesso em: $18 / \mathrm{mar} / 2012$.

PERSONA, Mario; Mudanças nas empresas. Disponível em: <http://www.mariopersona.com.br/entrevista revista melhor.html>. Acesso em: 17/mar/2012.

RIBEIRO, Raquel; O consumo: uma perspectiva sociológica. Disponível em: < http://www.aps.pt/vicongresso/pdfs/105.pdf>. Acesso em: 17/mar/2012.

SEVERINO, Antônio Joaquim. Metodologia do trabalho científico. São Paulo: Cortez Editora, 2009.

TROTTA, Henrique; $O$ impacto que a qualificação e valorização do atendimento podem ter no faturamento das empresas prestadoras de serviços. Disponível em: 
$<$ http://meuartigo.brasilescola.com/administracao/o-impacto-que-qualificacao-valorizacaoatendimento-.htm>. Acesso em 17/mar/2012.

WELLINGTON, Pat. Atendimento eficaz ao cliente. São Paulo: Clio Editora, 2011.

WERTHEIN, Jorge. A sociedade da informação e seus desafios. Disponível em: <http://www.scielo.br/pdf/ci/v29n2/a09v29n2.pdf >. Acesso em: 18/mar/2012.

ZAMBON, Marcelo Socorro; SILVA, Fábio Gomes. Atributos valorizados pelos clientes. In: SILVA, Fabio Gomes; ZAMBOM, Marcelo Socorro. Gestão do relacionamento com o cliente. São Paulo: Cengage Learning, 2012.

ZAMBON, Marcelo Socorro. Era do (e-) relacionamento e as regras da economia. In: SILVA, Fabio Gomes; ZAMBOM, Marcelo Socorro. Gestão do relacionamento com o cliente. São Paulo: Cengage Learning, 2012.

\section{Como citar esse artigo (ABNT):}

LUNA, İtalo M.; ALMEIDA NETO, José Leandro. As Técnicas de Atendimento de uma Empresa Localizada no Crato - CE. Id on Line Revista de Psicologia, Julho de 2014, vol.8, n.23, p. 126-151. ISSN 1981-1179. 